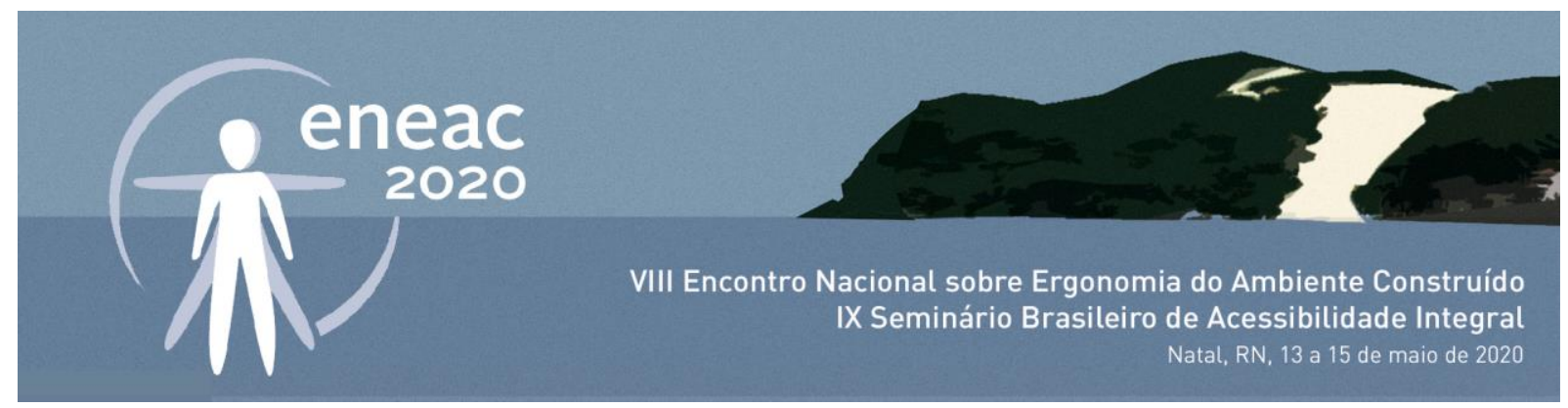

\title{
Estarão as Alices no país das maravilhas?
}

\author{
Will be the Alices in wonderland?
}

CAMILA ARCARO BEZ BATTI

Mestranda em Arquitetura e Urbanismo, Universidade Federal de Santa Catarina (UFSC), camilabezbatti@gmail.com

GABRIELA VARGAS RODRIGUES Mestra em Arquitetura e Urbanismo, Universidade Federal de Santa Catarina (UFSC), vargasrodriguesgabriela@gmail.com

MARCIA URBANO TRONCOSO Doutoranda em Arquitetura e Urbanismo, Universidade Federal de Santa Catarina (UFSC), marciaurbanotroncoso@gmail.com

VERA HELENA MORO BINS ELY Doutora em Engenharia de Produção, Universidade Federal de Santa Catarina (UFSC), vera.binsely@gmail.com

\section{RESUMO}

Neste artigo teve-se por objetivo a análise do ambiente de uma brinquedoteca, a fim de analisar os comportamentos gerados pelo espaço e mobiliário presente e verificar possíveis constrangimentos na realização de atividades, visando elaborar diretrizes projetuais para o planejamento de um espaço recreativo que atenda tanto à escala infantil quanto às necessidades das funcionárias. $O$ estudo fundamenta-se na aplicação de métodos como: visita exploratória, poema dos desejos, mapeamento visual, observação direta e sistemática, mapa comportamental e entrevistas. Dentre os principais resultados destacam-se: zoneamento por área e idade, criação de nova área lúdica, demarcação de espaço por meio da utilização de cores (quentes e frias), espaço de lazer destinado às funcionárias. 0 trabalho reflete sobre a compreensão do ambiente levando em consideração o ponto de vista das funcionárias, e sobre os atributos ambientais desejáveis para a sua adequação às características e necessidades de seus usuários, conforme preceitos da ergonomia e psicologia ambiental.

PALAVRAS-CHAVE: brinquedoteca, diretrizes projetuais, ergonomia, psicologia ambiental 


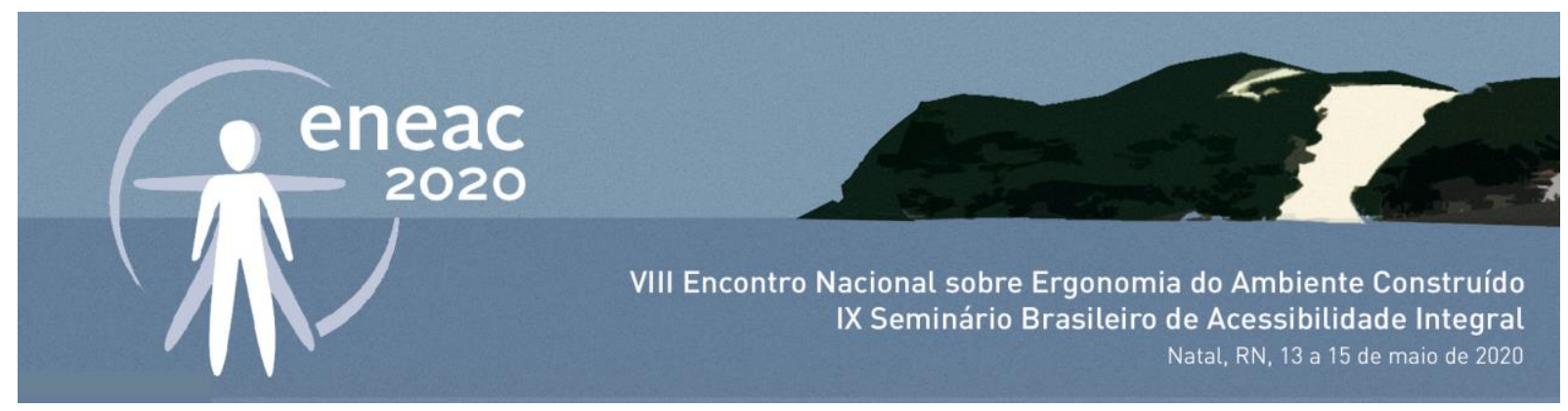

\begin{abstract}
The objective of this work was to analyze the environment of a toy library, in order to verify possible constraints, analyze the behaviors generated by space and furniture present, aiming to elaborate design guidelines for the planning of a recreational space that meets both the scale the needs of employees. The study is based on the application of methods such as: exploratory visit, Wish Poems, visual mapping, direct and systematic observation, behavioral map and interviews. Among the main results are: zoning by area and age, the creation of a new leisure area, demarcation of space through the use of colors (hot and cold), leisure space for employees. The work reflects on the understanding of the environment taking into account the point of view of the employees, and on the environmental attributes desirable for their adaptation to the characteristics and needs of their users, according to ergonomics and environmental psychology precepts.
\end{abstract}

KEYWORDS: toy library, design guidelines, ergonomics, environmental psychology

\title{
1 INTRODUÇÃO
}

Desde que cheguei a esse mundo, só escuto o que tenho que fazer e quem eu tenho que ser. Já fui encolhida, esticada, esfolada, escondida num bule de chá, já fui acusada de ser e não ser a Alice certa, mas esse sonho é meu, eu decido o que fazer a partir de agora, eu faço o meu destino. (CARROLL, 1865, apud RICO, 2015, p. 1).

Este artigo dá voz às "Alices" que trabalham como funcionárias em uma brinquedoteca, as quais foram contratadas para trabalhar especificamente como monitoras de crianças, mas acabam acumulando outras tarefas. Estas atividades extras prejudicam ainda mais a postura, refletindo dores corporais durante a jornada diária de 6 horas. Encolher e esticar corpos, que parecem gigantes, em relação à escala do ambiente adaptado para o público-alvo infantil, não parece ser uma situação ergonômica confortável em um ambiente de trabalho.

Pouco se ouve falar sobre a "qualidade de trabalho dos funcionários em estabelecimentos comerciais, principalmente relacionando ergonomia (antropometria e posturas) e psicologia ambiental" (SILVEIRA; BINS ELY, 2015). Uma das preocupações desta pesquisa é a qualidade do ambiente de trabalho das funcionárias, que podem apresentar dificuldades e constrangimentos ao realizar suas atividades diárias no espaço da brinquedoteca analisado, projetado para o público infantil. É fato que a movimentação e as posturas assumidas não dependem só do ambiente construído mas, também, se devem ao número de crianças no local e da sazonalidade. No verão, quando é considerada alta temporada, o local recebe um maior número de crianças se comparado ao inverno, com baixa temporada.

Não apenas as crianças, que passam entre 30 minutos à uma hora, devem ficar satisfeitas na brinquedoteca, mas, principalmente, quem passa a maior parte do tempo com a responsabilidade de cuidá-las e distraí-las por horas. Monitoras mais felizes refletem mais confiança aos clientes, já que por sua vez os pais que contratam este serviço também dependem do estado de humor e da atenção dispensados por essas Alices aos seus filhos, podendo assim fazer compras e/ou outras atividades com mais tranquilidade.

É importante que a brinquedoteca possua um espaço adequado para o fluxo de clientes, mas que também transmita conforto e segurança às funcionárias. A fim de evitar conflitos organizacionais no ambiente e promover equilíbrio entre as necessidades das Alices e crianças, de forma que sejam satisfatórias para ambos. 


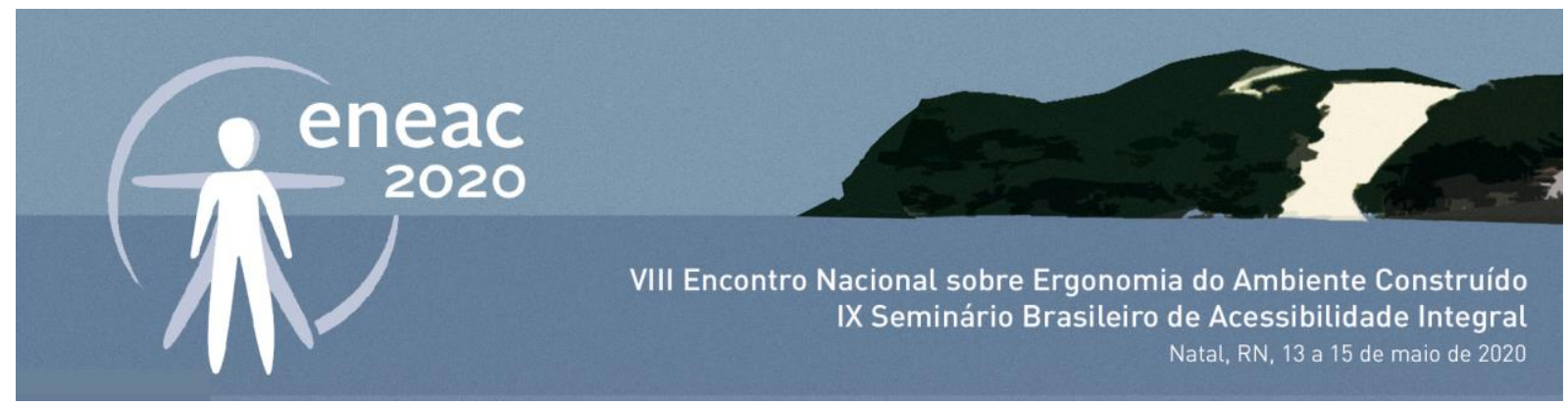

O ofício das funcionárias mencionadas tem por finalidade o atendimento as crianças (público-alvo da empresa). Segundo a CBO/MT (2020, p.1) as monitoras:

\begin{abstract}
Promovem atividades recreativas diversificadas, visando ao entretenimento, à integração social e ao desenvolvimento pessoal dos clientes. Para tanto, elaboram projetos e executam atividades recreativas; promovem atividades lúdicas, estimulantes à participação; atendem clientes, criam atividades recreativas e coordenam setores de recreação; administram equipamentos e materiais para recreação. As atividades são desenvolvidas segundo normas de segurança.
\end{abstract}

A princípio, o estabelecimento encontra um grande problema em relação aos mobiliários e equipamentos, que normalmente não são adaptados para seus funcionários, somente para o públicoalvo, ou seja, as crianças. Por sua vez, surgem problemas e constrangimentos no desempenho das tarefas pelas monitoras.

Ao avaliar o espaço do ponto de vista das Alices, o presente trabalho propõe ao final, diretrizes projetuais com alterações no layout, além de outras sugestões. A proposta terá como objetivo tentar suprir as necessidades das diferentes escalas e melhorar o ambiente para o conforto das monitoras e das crianças, dentro da mesma metragem quadrada.

\title{
1.1 LOCAL ANALISADO
}

Localizado em um shopping center, o objeto de estudo está próximo ao centro urbano de uma cidade turística ao sul do Brasil. A brinquedoteca possui em média $95 \mathrm{~m}^{2}$ divididos entre térreo e mezanino, que podem ser observados em setores na figura 1.

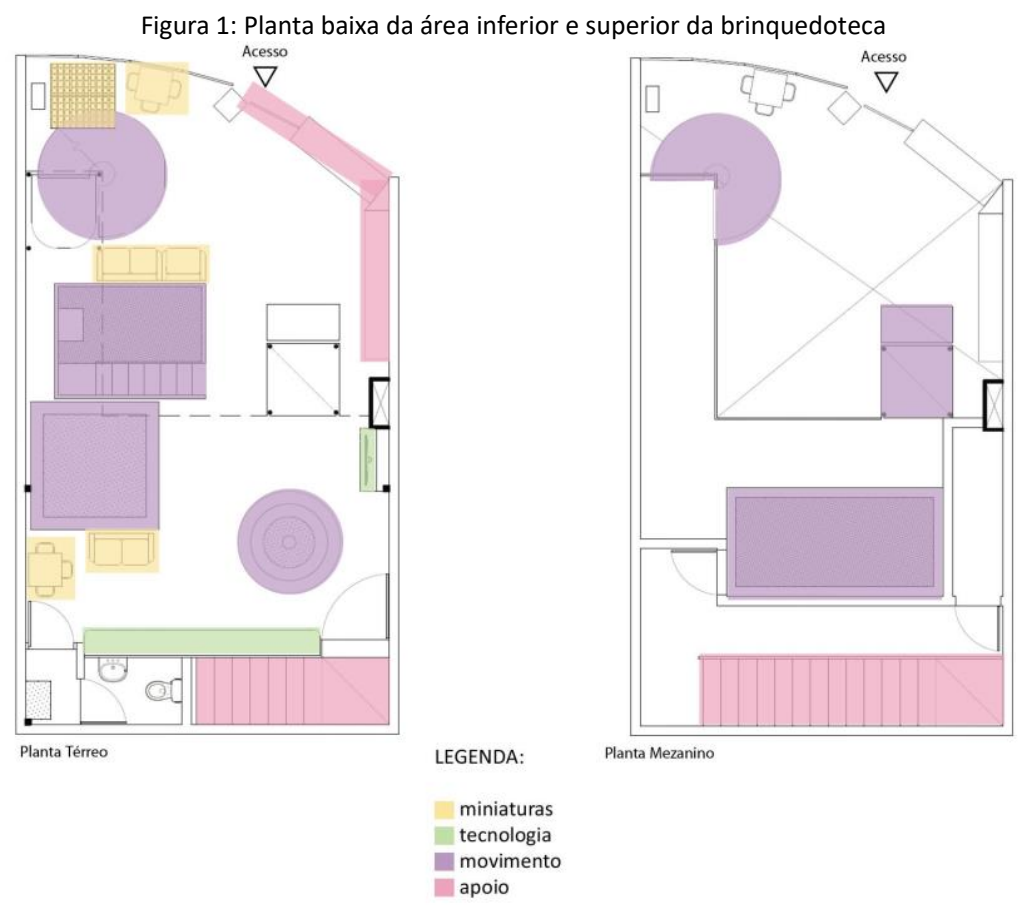

Fonte: Autoras, 2020. 


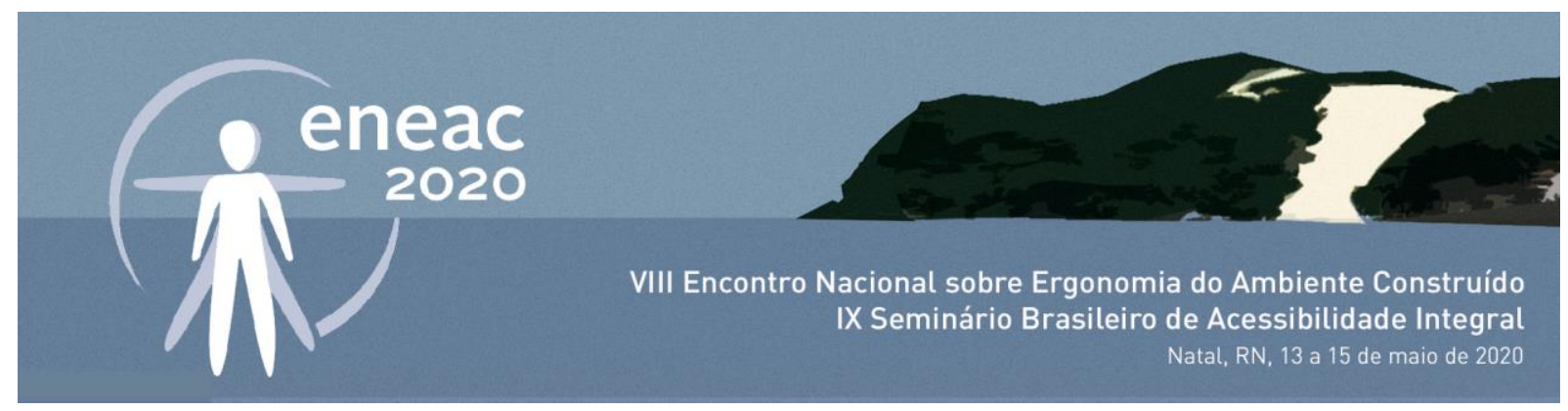

O setor miniaturas (em amarelo) é onde se destacam brinquedos para a menor faixa etária. Nele podemos encontrar uma casinha infantil, móveis para auxílio de brincadeiras e espaço para desenhar. No local de tecnologia (em verde) encontram-se os jogos eletrônicos, para adolescentes. A área destinada ao movimento (na cor lilás) é definida pelo espaço onde estão brinquedos como cama elástica, piscina de bolinhas e escorregador, para as crianças de todas as idades. E o setor de apoio (em cor de rosa) é exclusivamente de utilização das monitoras, onde encontram-se a parte administrativa e de descanso das funcionárias.

A brinquedoteca possui o horário de funcionamento das 10:00 às 22:00 horas, de segunda a sábado e das 12:00 às 20:00 horas aos domingos e feriados. Comporta aproximadamente até 25 crianças no verão, época com maior clientela. A brinquedoteca atende crianças entre 2 anos (acompanhadas por pais ou responsáveis) até a idade máxima de 12 anos. As cinco funcionárias do local são do sexo feminino, uma preferência de gênero no momento da contratação. As monitoras - nome dado às funcionárias - possuem turno de 6 horas de trabalho, com apenas um dia da semana para folga, sendo a escala definida por elas mesmas.

\section{REFERENCIAL TEÓRICO}

Na década de 1930 surgiu em Los Angeles o primeiro programa de uma brinquedoteca. Com o objetivo de "solucionar problemas de furtos frequentes de brinquedos em uma loja, o proprietário decide relatar o ocorrido para o diretor da escola municipal local sobre esses desvios de comportamentos de seus alunos". Foi, então, que o diretor da escola "percebeu que esses roubos eram decorrentes devido à falta de brinquedos disponíveis às crianças de sua instituição". Desta maneira, o diretor criou o primeiro projeto de brinquedoteca, oferecendo aos alunos brinquedos variados que poderiam ser explorados in loco ou emprestados (LIMA; DELMÔNICO, 2010).

Entretanto foi somente em 1963 que esta ideia foi irradiada. Com o "objetivo de emprestar brinquedos e fornecer informações às famílias de crianças com deficiência intelectual sobre como poderiam brincar com seus filhos e como estimulá-los", duas professoras fundaram a ludoteca (termo também utilizado para denominar uma brinquedoteca) em Estocolmo (ABBRI, 2017).

No Brasil, as brinquedotecas surgiram apenas em 1981, quando foi montada a primeira do país, a Brinquedoteca Indianópolis, em São Paulo, tendo como "diretora, a responsável pela criação do termo Brinquedoteca, a pedagoga Nylse Cunha" (ABBRI, 2017). Desde 1984, existe a Associação Brasileira de Brinquedotecas (ABBri) que trabalha divulgando o ato de brincar, se preocupa com a formação de monitoras e auxilia na montagem das brinquedotecas pelo país, sendo referência nacional em consultoria e na capacitação dos empregadores seguindo os padrões internacionais da Associação Internacional de Brinquedotecas (ITLA). No entanto, a ABBri não fornece diretrizes projetuais para montagem de brinquedotecas pelo país, apenas consultoria.

Com o tempo e a rotina intensa dos adultos, surgiu o movimento do uso de espaços de interação e convívio para as crianças (brinquedotecas) em locais especificamente comerciais. Dessa forma, ao mesmo tempo em que a criança aprende e pode ser instigada, os pais veem seu tempo otimizado, e se sentem tranquilos para poder fazer outras atividades, como compras no supermercado ou pagamento de contas. A abertura desse nicho fez com que surgisse uma nova função: o de monitora de recreação. 


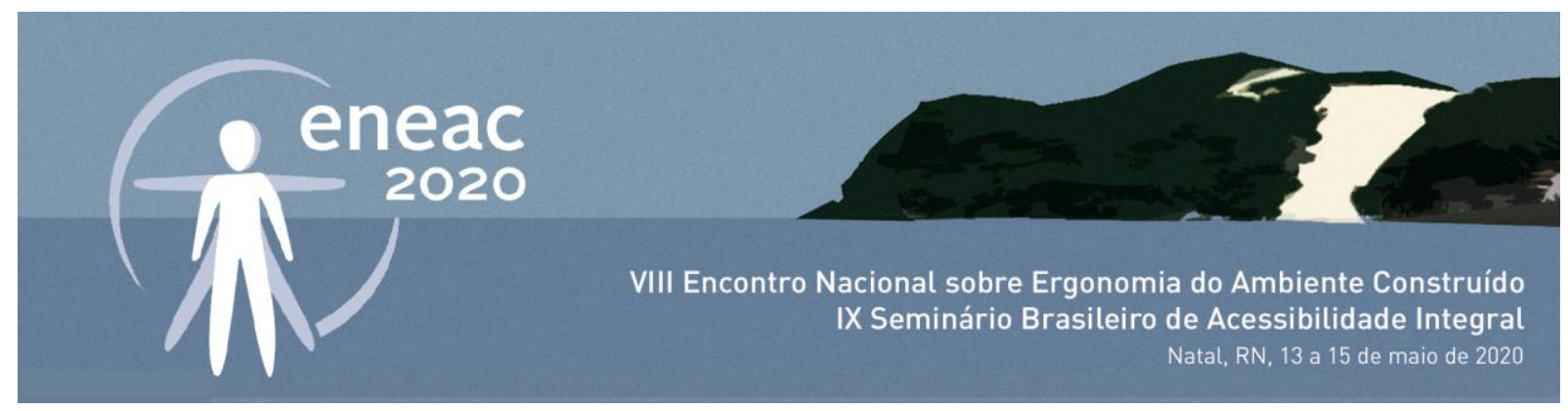

As brinquedotecas fornecem recursos para brincadeiras, pessoal treinado e espaço específico. "O ato de brincar envolve brinquedos e jogos, que por sua vez estão no centro das atividades. Geralmente, uma brinquedoteca é um recurso da comunidade que atende pessoas sem levar em conta a língua, origem nacional, idade, sexo, deficiência ou religião" (ITLA, 2020).

Em se tratando de atividades direcionadas para crianças, uma brinquedoteca destaca a vivência lúdica entre os indivíduos no ambiente, cujas características espaciais podem ser um facilitador ou um dificultador das atividades que serão realizadas. Além das crianças, seria importante considerar todos os agentes do lugar, principalmente seus funcionários, pois serão seus usuários mais frequentes.

\subsection{PSICOLOGIA AMBIENTAL E AS INTER-RELAÇÕES DA AVALIAÇÃO ERGONÔMICA}

Nessa perspectiva de estudos do ambiente de trabalho, existe a linha da Psicologia Ambiental que "estuda as inter-relações humano-ambientais, dirigindo o olhar para o indivíduo e seus diversos comportamentos e atitudes em um dado ambiente" (MOSER, 1998). Acredita-se que o ambiente construído pode afetar seus usuários tanto fisicamente quanto psicologicamente. Como definição, na Psicologia Ambiental, "a pessoa tem propriedades ambientais tanto quanto propriedades psicológicas individuais. O homem é ele mesmo um componente ambiental e, como ele interage com seu meio, ajuda a determinar a natureza do meio e seus efeitos sobre suas ações" (ITTELSON et al., 1974).

Segundo Cavalcante (2003), "os estudos dessas inter-relações constitui a Psicologia Ambiental e são configurados por uma investigação geralmente feita por um dos lados dessa relação".

Complementando, Bell et al. (1978) comentam que "o ambiente não dita o comportamento dos usuários, porém essa inter-relação faz com que um não possa ser compreendido separado do outro".

Outro conceito destacado pela Psicologia Ambiental são os estudos de privacidade e territorialidade. O conceito de "privacidade relaciona-se a como falamos, como nos expressamos não verbalmente e aos nossos processos de desenvolvimento. Esta privacidade pode ser medida como um comportamento, uma crença, um valor, uma preferência ou uma expectativa". Este termo está interligado ao de territorialidade, pois "é na adequação do espaço onde nos sentimos confortáveis e seguros, sendo nosso espaço privado" (GIFFORD, 1987).

Cada indivíduo carrega suas experiências, estratégias e representações e as emprega com a intenção de regular o processo de produção, partindo do princípio que estes não são idênticos na situação de trabalho. Este pensamento corrobora com os estudos de ergonomia. "Uma avaliação ergonômica deve levar em consideração que a atividade não se constitui só pela variação de situações de trabalho, mas também pelas diferentes equipes que as executam" (ABRAHÃO et al., 2009).

Para manter uma postura ou realizar um movimento, vários e diferentes músculos são acionados, assim como articulações e ligamentos. "Os músculos são responsáveis pela força na adoção de uma postura ou na execução de um movimento, as articulações permitem um deslocamento de partes do corpo em relação a outras e os ligamentos desempenham uma função auxiliar em todo esse conjunto de estruturas. Posturas ou movimentos inadequados levam a tensões mecânicas nos músculos, ligamentos e articulações, podendo gerar dores em diferentes regiões corporais, como no pescoço, costas, ombros, punhos", por exemplo (DUL; WEERDMEESTER, 2004). 


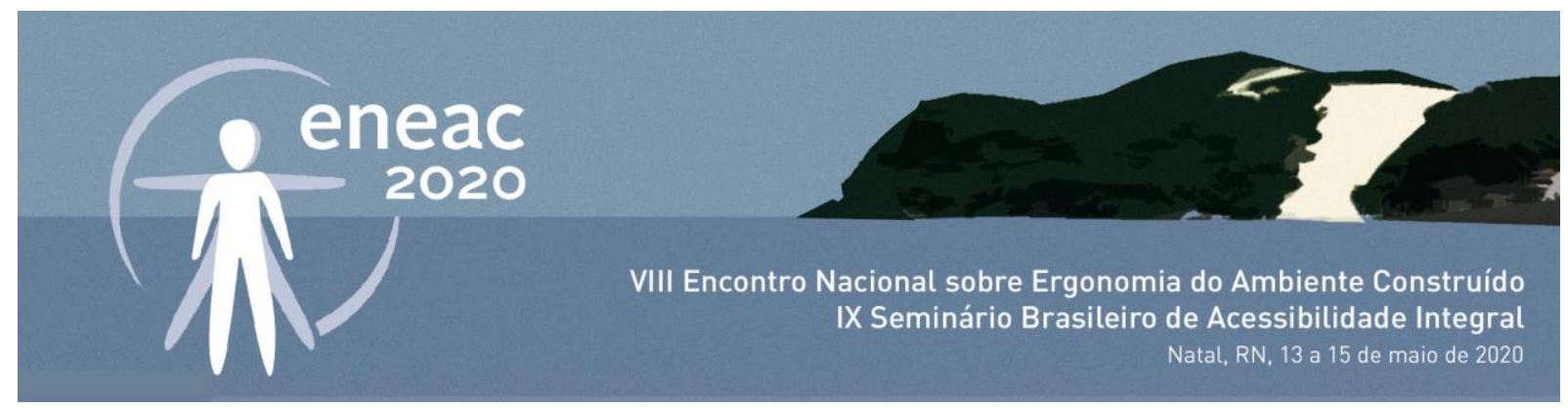

E ainda, complementado por Kroemer e Grandjean (2005), "os esforços prolongados e repetitivos podem gerar desgaste e lesões das articulações, ligamentos e tendões, que são geralmente conhecidos sob o termo distúrbios musculoesqueléticos". Mesmo o trabalho muscular estático moderado pode causar fadiga localizada nos músculos envolvidos, podendo evoluir para dores insuportáveis.

Para criação de uma proposta que considere o ponto de vista das monitoras, no ambiente de trabalho analisado, foram feitos alguns estudos de Ergonomia e Psicologia Ambiental, elaborados durante um processo de 3 meses, que utilizou os métodos descritos a seguir.

\section{METODOLOGIA}

A pesquisa possui caráter exploratório, interdisciplinar e qualitativo, com abordagem multimétodos, baseando-se nos preceitos da Ergonomia e da Psicologia Ambiental. A utilização de diferentes métodos permitiu um aprofundamento do tema, além de trazer à tona os desejos, expectativas e anseios dos usuários de vários pontos de vista, facilitando sua compreensão. Os métodos serão apresentados de acordo com a ordem que foram aplicados.

\section{- Visita exploratória.}

Na visita exploratória buscou-se introduzir a pesquisa às funcionárias, de modo que as mesmas pudessem familiarizar-se com a presença das pesquisadoras no local. Foi realizada uma entrevista com a gerente do estabelecimento, visando um entendimento inicial do ponto de venda e de seu funcionamento, bem como a compreensão da escala de trabalho das funcionárias para posterior visita. Um levantamento físico foi realizado para medição do local e confecção de plantas e elevações.

\section{- Poema dos Desejos.}

O método do "Poema dos Desejos" (SANOFF, 1990) tem por objetivo compreender as expectativas, anseios e desejos dos usuários em relação ao ambiente. Foi entregue às cinco funcionárias do estabelecimento um formulário em branco, constando uma breve apresentação da pesquisa e, após essa introdução, destacava-se a seguinte frase: "Eu gostaria que a brinquedoteca fosse ou tivesse...". A participante era então convidada para expressar livremente o que acreditava ser desejável para o ambiente da brinquedoteca por meio de textos ou desenhos. Como este tipo de método não direciona nenhum tipo de resposta favorece a compreensão de quais são os aspectos importantes ou desejáveis para o local do ponto de vista de quem responde.

\section{- Mapeamento visual.}

"Criado por Ross Thorne e Jeffrey Turnbull, em 1991", (RHEINGANTZ et al., 2009), o método permite a coleta de informações no que diz respeito à percepção do ambiente pelos usuários, embora também possa fornecer informações sobre o comportamento ambiental. É um método de fácil compreensão e aplicação, favorecendo uma maior variedade de respostas. Além disso, auxilia no desenvolvimento de recomendações projetuais, ao evidenciar quais características do ambiente são positivas ou negativas na percepção de seus usuários.

Para a aplicação do método, foi apresentada uma planilha com uma elevação em perspectiva do local, na qual se solicitava à monitora que registrasse possíveis aspectos positivos ou negativos do 


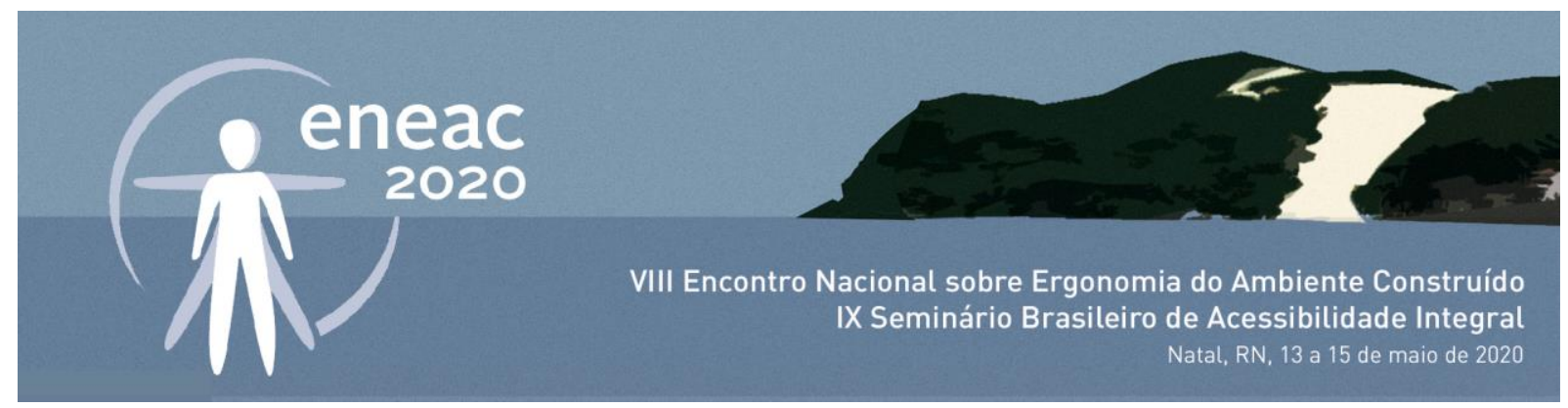

ambiente. Assim, tornou-se possível não apenas detectar problemas específicos, como localizá-los espacialmente.

\section{- Observação direta e sistemática.}

Foram realizadas "observações diretas e sistemáticas" (RHEINGANTZ et al., 2009) das usuárias utilizando o ambiente da brinquedoteca. Objetivou-se compreender: suas atividades, rotinas, necessidades e características, possíveis constrangimentos e padrões comportamentais no local. Foram observadas as cinco funcionárias durante seu turno de trabalho. As observações foram centradas no ambiente e, portanto, a pesquisadora ficou parada no local registrando o que observava de forma menos intrusiva possível. Os registros foram feitos de modo escrito e por fotografias; duraram cerca de uma hora para cada funcionária analisada.

\section{- Mapa comportamental.}

"Consiste em registrar informações observadas sobre a planta do local. Esse método é capaz de identificar usos, arranjos espaciais, fluxos e suas relações, bem como é possível identificar graficamente os movimentos, interações e distribuição dos usuários pelo ambiente" (RHEINGANTZ et al., 2009). Nesta pesquisa, o objetivo foi avaliar os fluxos, atividades e os comportamentos das funcionárias em seus respectivos horários de trabalho. Cada monitora foi observada durante uma hora.

\section{- Entrevistas semiestruturadas.}

As entrevistas foram realizadas a partir de um roteiro semiestruturado, a fim de compreender alguns temas específicos. Foram entrevistadas as cinco funcionárias com o intuito de entender quais as principais características do ambiente que impactam diretamente na vivência, suas necessidades espaciais, a jornada de trabalho, o que fazem em seu momento de lazer, entre outras questões. Durante a entrevista foi aplicado o "Diagrama de Corlett e Manenica" (IIDA, 2005) para verificar se existiam incômodos físicos no local e se havia motivos que tornassem o trabalho estressante.

\section{RESULTADOS}

Os dados obtidos nos métodos acima descritos foram tratados de forma qualitativa por meio de "Análise de Conteúdo" (BARDIN, 2011), utilizando as seguintes categorias como referência: conforto, segurança e territorialidade.

Boa parte dos resultados está relacionada ao conforto do usuário, visando proporcionar condições favoráveis para a realização das tarefas, demandando o mínimo possível de força física e de posturas inadequadas. Estes resultados incluem aspectos relativos à: favorecer a adoção de uma postura neutra, facilitar os alcances vertical e frontal, demandar menos força física, favorecer a acessibilidade, disponibilizar espaço de descanso, dentre outros. Observa-se que boa parte dos aspectos, apontados pelas participantes ou constatados pelas pesquisadoras, relaciona-se à ergonomia - mais especificamente, antropometria e biomecânica. Esses aspectos, ao serem considerados nas etapas de planejamento e projeto do ambiente, são fundamentais para evitar fadiga e lesões, favorecendo o bem-estar das usuárias.

Outro atributo bastante recorrente nos resultados é a segurança. O conceito de segurança refere-se aos aspectos do ambiente e do mobiliário. A reorganização dos brinquedos minimizaria o risco de acidentes, entre crianças de diferentes faixas etárias. Em relação a esse aspecto, busca-se segmentar 


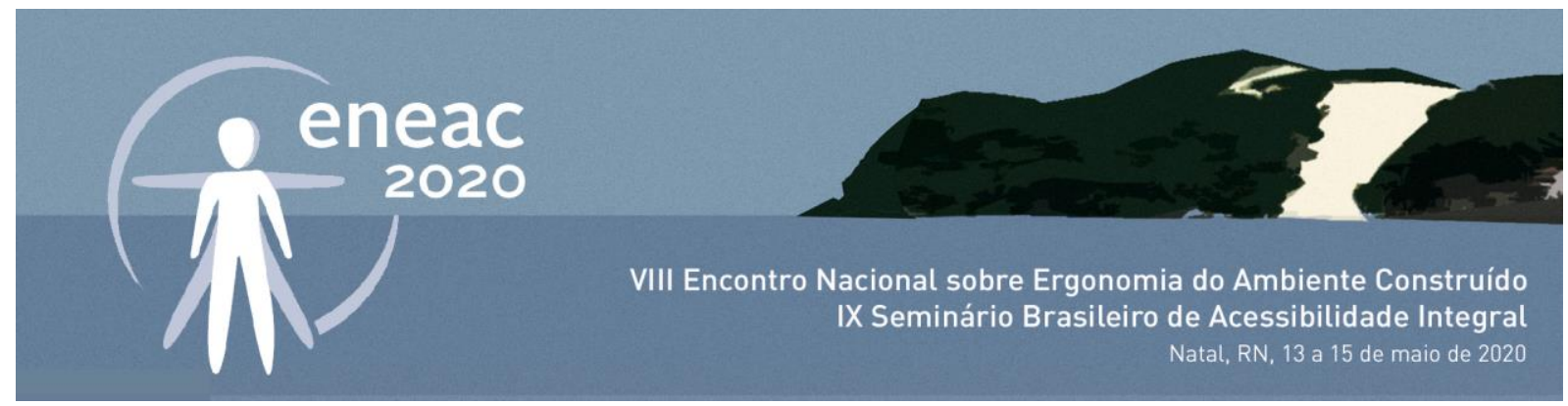

as áreas ou componentes, facilitando a visualização rápida das crianças. Explorar diferentes cores e formas, bem como o contraste entre eles, pode auxiliar na setorização dos espaços.

Por fim, o conceito de territorialidade condiz com a setorização da brinquedoteca de acordo, justamente, com a função dos brinquedos dispostos nessa área e sua aproximação por similaridade. Além da organização, é preciso maximizar a área de descanso e lazer das funcionárias, atualmente inexistente, permitindo a maior qualidade nos 15 minutos de descanso das mesmas, restaurando a energia e atenção.

Pode-se observar ainda uma discrepância em relação ao que de fato é feito na brinquedoteca e o que a CBO/MT (2020) comenta sobre o cargo de monitora, pois a Alice 01 cita: "a gente tem que fazer tudo aqui, tem que cuidar, ficar no caixa, a gente tem que tomar cuidado pras crianças não mexerem no caixa e tal", "[...] a gente que limpa as piscinas, às vezes limpa os tatames que fica bem sujo, a gente tem que manter limpo, ela (a gerente) faz escala de limpeza pra gente, e isso é feito no horário de trabalho mesmo".

A partir da análise comparativa dos resultados foram sintetizadas diretrizes e alternativas projetuais relacionadas aos principais atributos desejáveis ao ambiente da brinquedoteca. Parte dessas diretrizes foram apontadas pelos participantes do estudo, enquanto resultados obtidos na aplicação dos métodos. Outras se baseiam em consultas durante a revisão de literatura e no conhecimento técnico das pesquisadoras. As figuras 2 e 3 expostas abaixo sintetizam os principais resultados e diretrizes projetuais obtidos em cada método aplicado. 


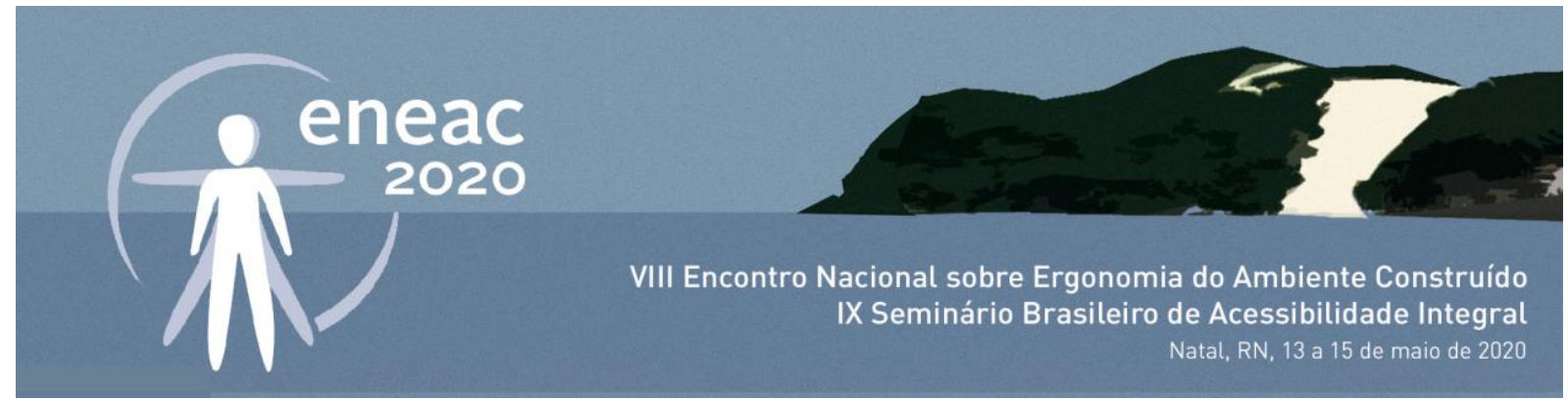

Figura 2: Quadro síntese com os principais resultados e diretrizes

\begin{tabular}{|c|c|c|}
\hline $\begin{array}{l}\text { Métodos em que foram } \\
\text { evidenciados }\end{array}$ & Principais resultados & Diretrizes projetuais \\
\hline $\begin{array}{l}\text { Visita exploratória } \\
\text { Poema dos Desejos } \\
\text { Observação direta e } \\
\text { sistemática } \\
\text { Mapeamento visual } \\
\text { Mapa comportamental } \\
\text { Entrevistas }\end{array}$ & 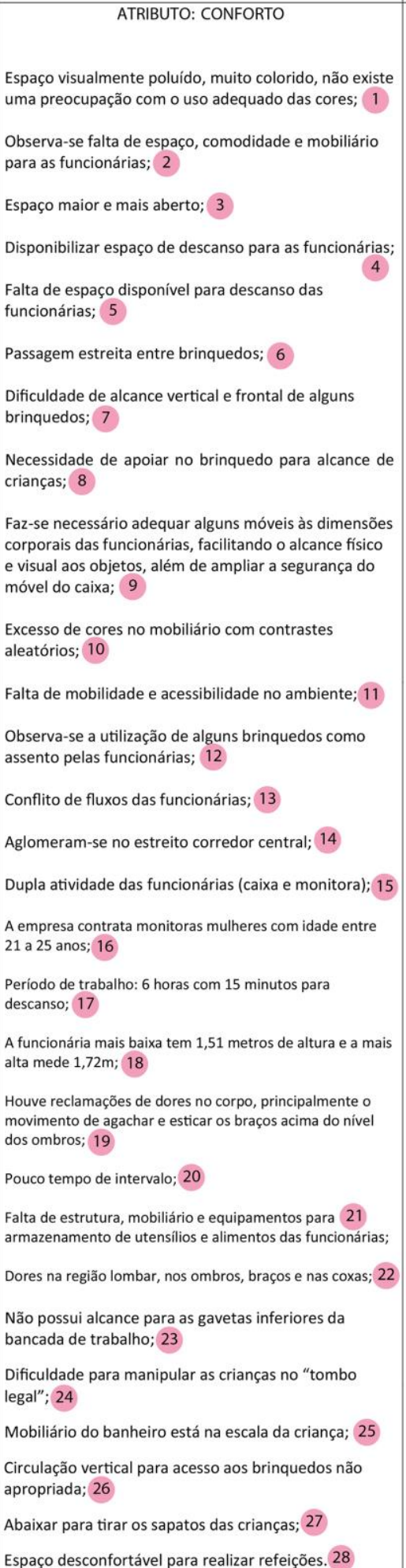 & 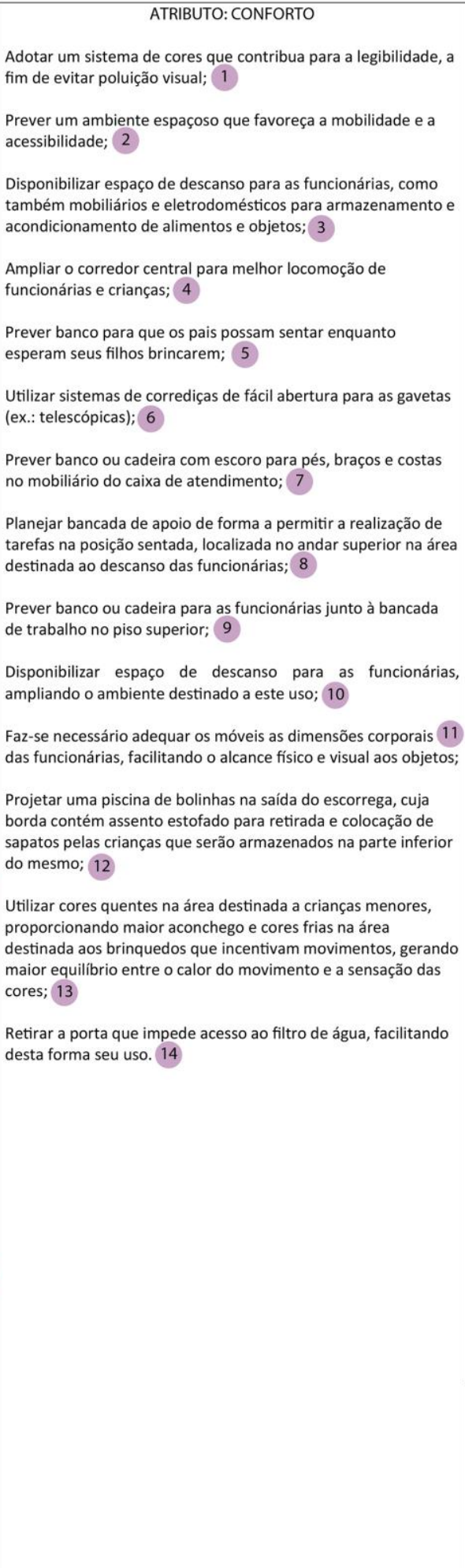 \\
\hline
\end{tabular}




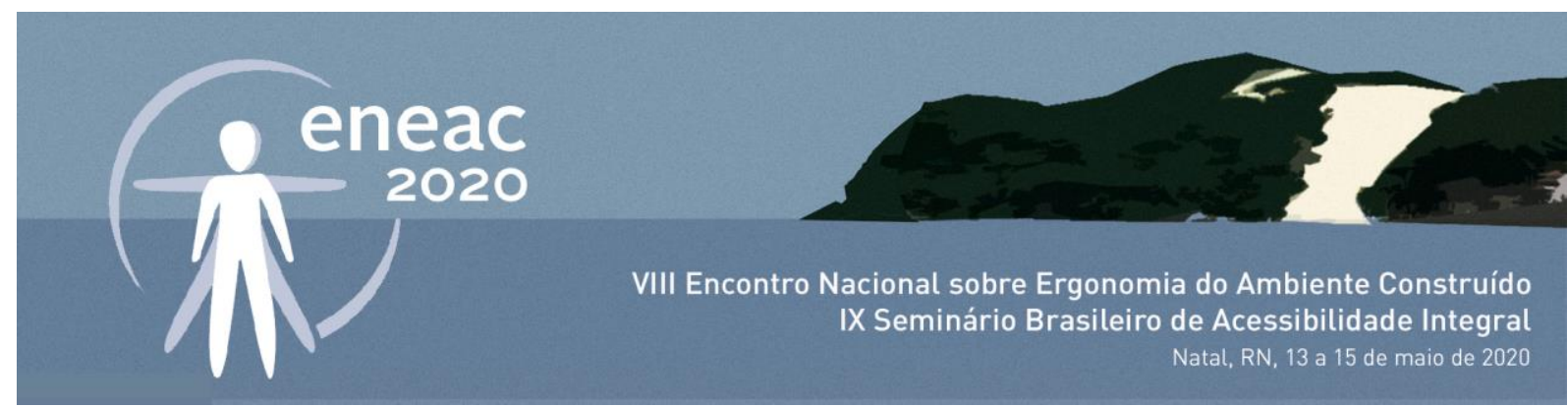

\begin{tabular}{|c|c|c|}
\hline $\begin{array}{l}\text { Poema dos Desejos } \\
\text { Observação direta e } \\
\text { sistemática } \\
\text { Mapeamento visual } \\
\text { Mapa comportamental } \\
\text { Entrevistas }\end{array}$ & $\begin{array}{l}\text { ATRIBUTO: SEGURANÇA } \\
\text { Observa-se a falta de setorização do ambiente; } 29 \\
\text { Mais segurança na área do caixa que está muito } \\
\text { exposto ao corredor do shopping; } 30 \\
\text { Ampliar a visão do andar de cima onde está localizada } \\
\text { a piscina de bolinhas; } 31 \\
\text { Visão limitada do mezanino; } 32 \\
\text { Falta de segurança no mobiliário do caixa de } \\
\text { atendimento; } 33 \\
\text { Falta de setorização nas áreas de atividades lúdicas; } 34 \\
\text { Presença de cantos vivos nos móveis; } 35 \\
\text { Dificuldade para acesso e fechamento de gavetas do } \\
\text { mobiliário do caixa; } 36 \\
\text { A posição do mobiliário do caixa deixa as funcionárias } \\
\text { de costas para as crianças. } 37\end{array}$ & $\begin{array}{l}\text { ATRIBUTO: SEGURANÇA } \\
\text { Setorizar as áreas lúdicas da brinquedoteca através das cores } \\
\text { para categorizar as crianças por idade; } 15 \\
\text { Dar preferência às formas dos móveis sem quinas vivas, } \\
\text { minimizando lesões por colisão; } 16 \\
\text { Retirar alguns brinquedos que causam desconforto nas } \\
\text { funcionárias e são mais propícios a acidentes nas crianças, como } \\
\text { o caso do brinquedo denominado Tombo legal; } 17 \\
\text { Prever espelho no teto da loja que reflita o mezanino para } \\
\text { ampliar a visão da funcionária que está no andar inferior; } 18 \\
\text { Adotar sistema automatizado para abertura e fechamento da } \\
\text { porta de acesso a brinquedoteca; } 19 \\
\text { Reposicionar alguns brinquedos para facilitar a sua usabilidade; } \\
\text { Segmentar a área destinada ao móvel do caixa de atendimento, } \\
\text { desta forma aumentando a segurança e limitando o acesso ao } \\
\text { mesmo; } 21\end{array}$ \\
\hline $\begin{array}{l}\text { Poema dos Desejos } \\
\text { Observação direta e } \\
\text { sistemática } \\
\text { Mapeamento visual } \\
\text { Mapa comportamental } \\
\text { Entrevistas }\end{array}$ & $\begin{array}{l}\text { ATRIBUTO:TERRITORIALIDADE } \\
\text { Brinquedos mal posicionados de acordo com a } \\
\text { funcionalidade; } 38 \\
\text { Há uma sobreposição de mobiliários e brinquedos que } \\
\text { deixam o ambiente com aspecto sufocante; } 39 \\
\text { Aumentar as opções de brinquedos didáticos. } 40\end{array}$ & $\begin{array}{l}\text { ATRIBUTO:TERRITORIALIDADE } \\
\text { Posicionar os brinquedos de acordo com sua funcionalidade, } \\
\text { aproximando os que possuem funções parecidas; } 24 \\
\text { Planejar novos brinquedos que complementem a simulação de } \\
\text { uma pequena cidade lúdica; } 25 \\
\text { Projetar ambiente destinado à escala infantil, aproveitando a } \\
\text { área do pé direito mais baixo; } 26 \\
\text { Prever ambiente mais privativo para descanso das funcionárias; } \\
\text { Incluir novas opções de brinquedos didáticos, incentivar a } \\
\text { criança no desenvolvimento cognitivo/motor; } 28 \\
\text { Prever área destinado a jogos virtuais e computadores } \\
\text { utilizados por crianças mais velhas na parte superior da } \\
\text { brinquedoteca, onde exige menos presença das monitoras. } 29\end{array}$ \\
\hline
\end{tabular}

Fonte: Autoras, 2020. 


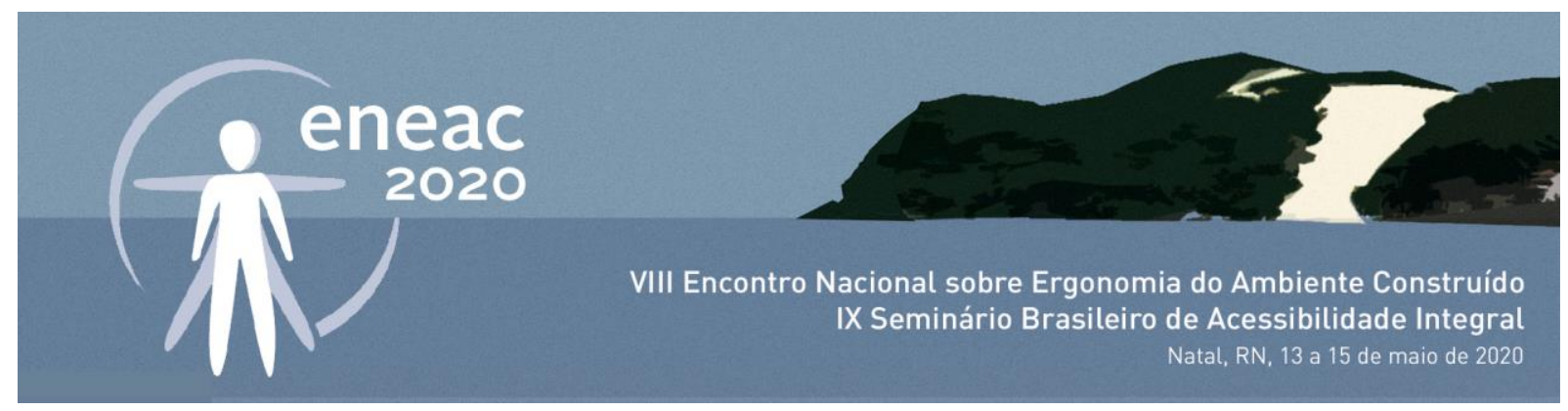

Figura 3: Planta baixa térreo e mezanino com os principais resultados numerados e localizados em planta, de acordo com o quadro síntese

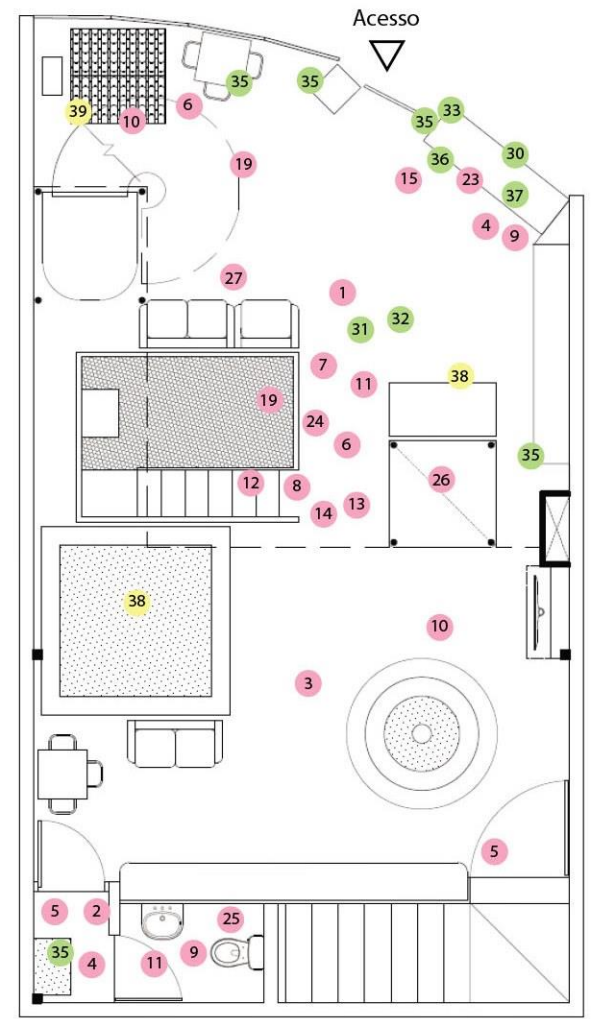

Planta Térreo

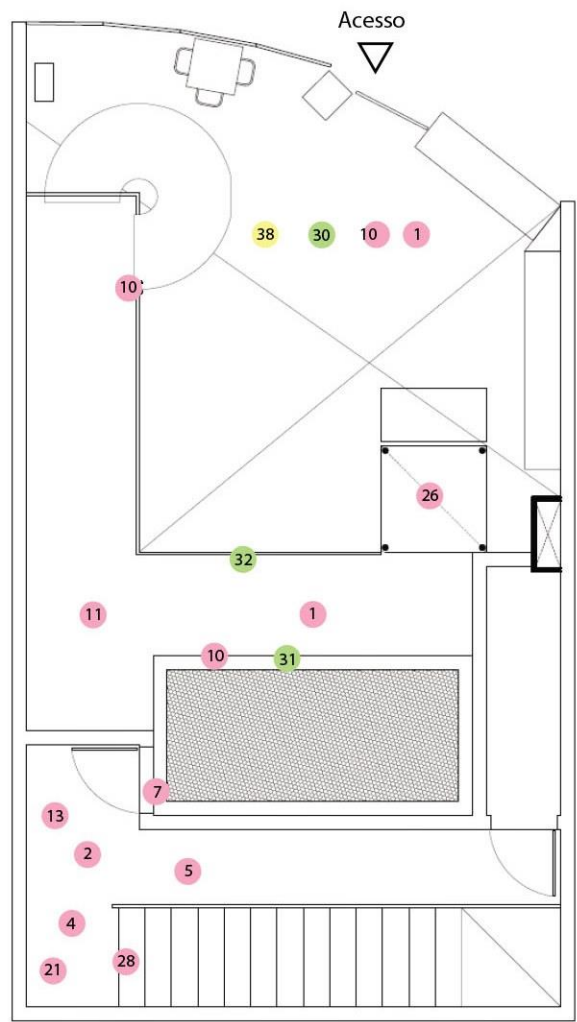

Planta Mezanino

Fonte: Autoras, 2020.

\section{PROJETO}

Segundo Robert Gifford (1987), "a privacidade é uma importante dimensão do nosso dia a dia, que busca equilibrar nossos desejos com o dos outros no meio ambiente, sendo assim, o design de um ambiente de trabalho deve ajudar nossa vida, propiciando espaços com mais ou menos privacidade". Ainda, segundo o autor, "a invasão de privacidade é um problema que pode ser tratado de forma multidisciplinar, vários profissionais tais como psicólogos, sociólogos, designers e arquitetos podem contribuir com seus diferentes conhecimentos" (GIFFORD, 1987). Portanto, foi proposto um novo layout para a brinquedoteca analisada, fruto da reflexão do quadro avaliativo que busca solucionar os problemas sob o ponto de vistas das Alices.

A desejada territorialidade das monitoras pode ser facilmente resolvida, ao reordenar alguns setores da brinquedoteca e assim otimizar a metragem quadrada ociosa do mezanino, onde atualmente as funcionárias possuem apenas uma pequena área de circulação. Ao descer a piscina de bolinhas para o primeiro pavimento, resolvem-se pontos falhos do ambiente: a falta de visibilidade das crianças que usam o brinquedo na área do mezanino; o problema do impacto das crianças que descem pelo escorregador e caem na piscina de bolinhas localizada debaixo da saída do mesmo. Além de deixar as crianças mais visíveis, facilita o controle das monitoras. Com mais espaço disponível no mezanino, este pode ser melhor aproveitado. 


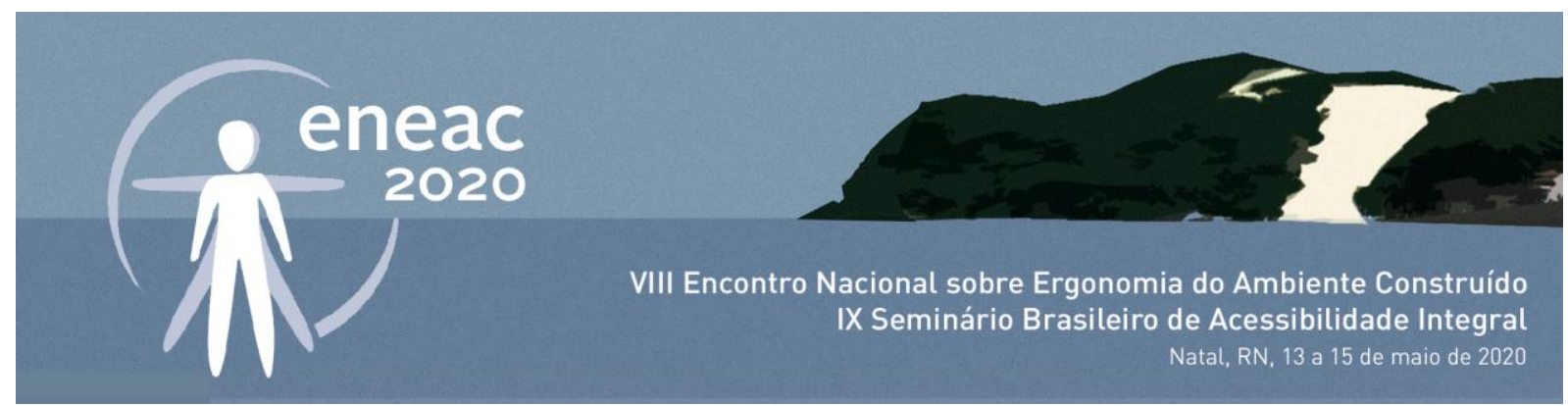

Ao afastar uma parede para aumentar a área destinada para as funcionárias no mezanino, acarreta em espaço vago e disponível para reinstalar a bancada de computadores destinada aos jovens, separando assim os usuários com mais idade no andar superior dos que possuem menos idade no andar inferior. Desta forma cria-se um território específico e mais silencioso para os games. Abaixo na figura 4 encontram-se as plantas do estabelecimento com o novo layout proposto e a comparação com o atual, indicando novos setores como a área privativa e de apoio para as funcionárias no andar superior.

Figura 4: Zoneamento da área inferior e superior do layout atual x layout nova proposta

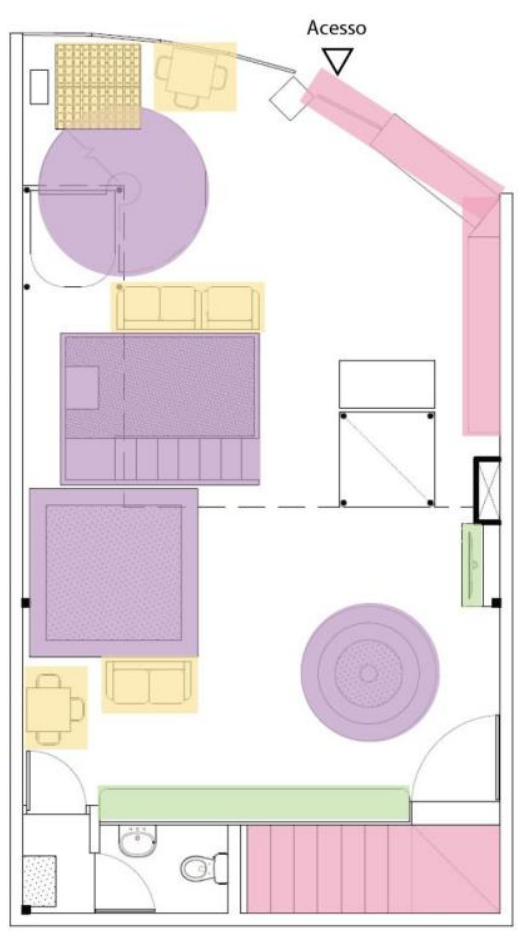

Planta Térreo - atual

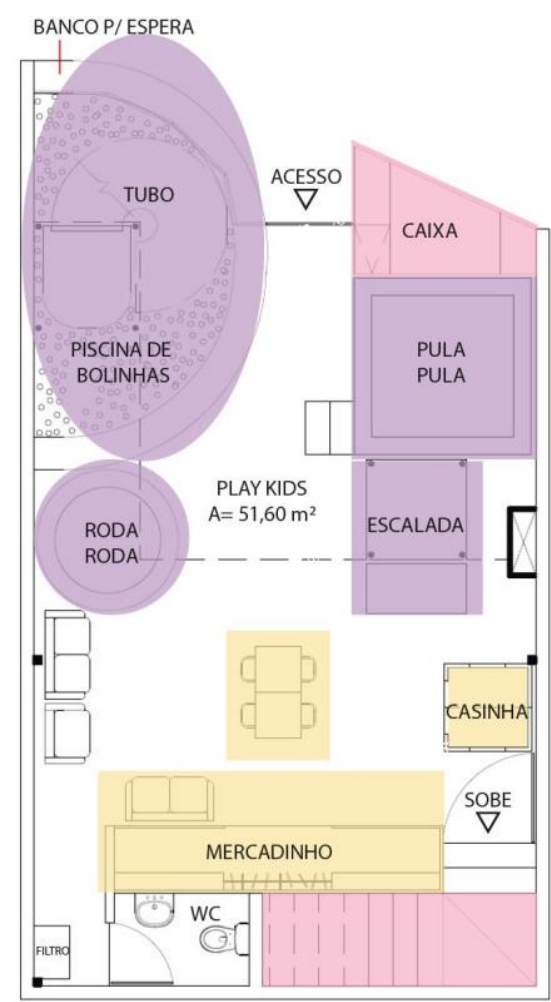

Planta Térreo - nova proposta

LEGENDA: 


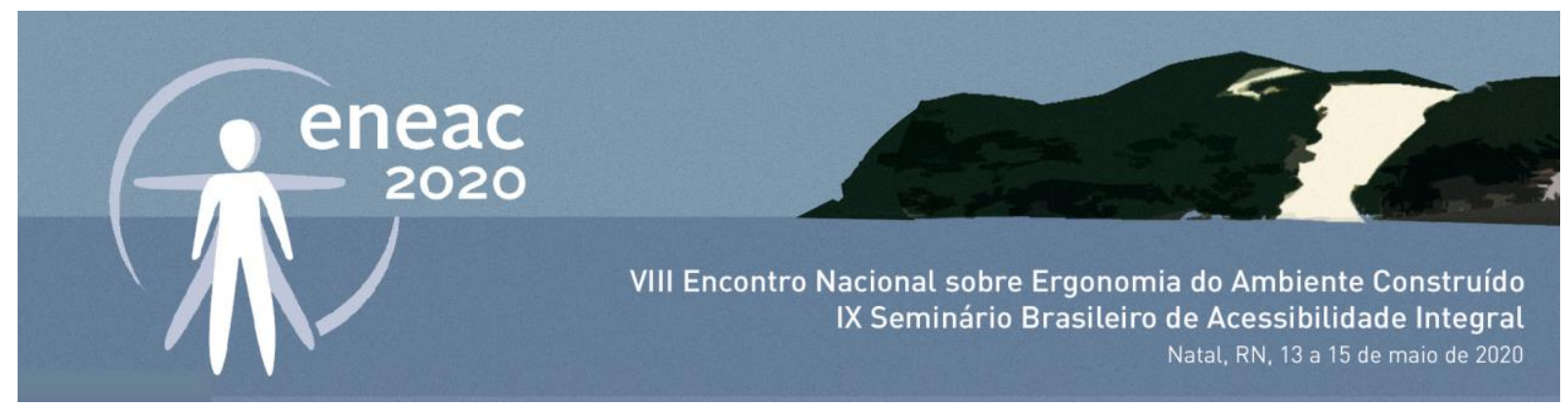

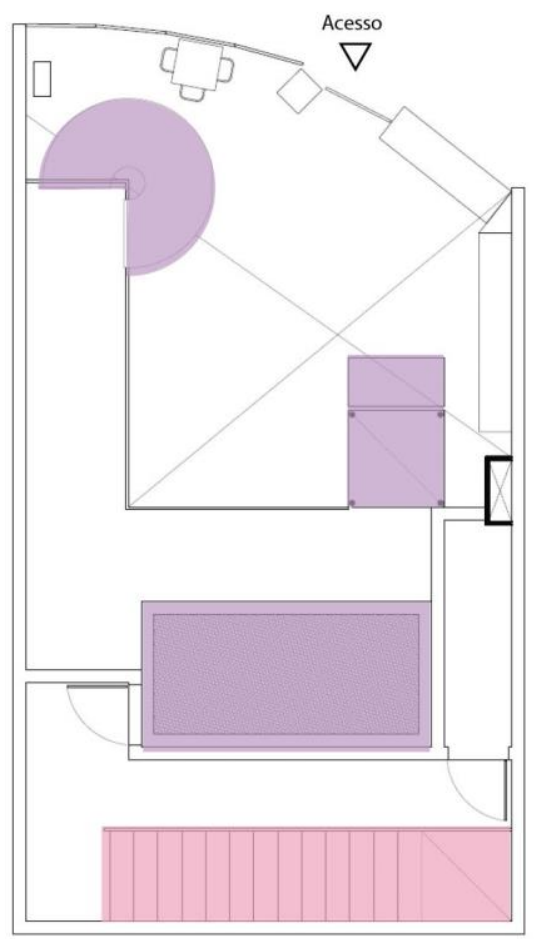

Planta Mezanino - atual

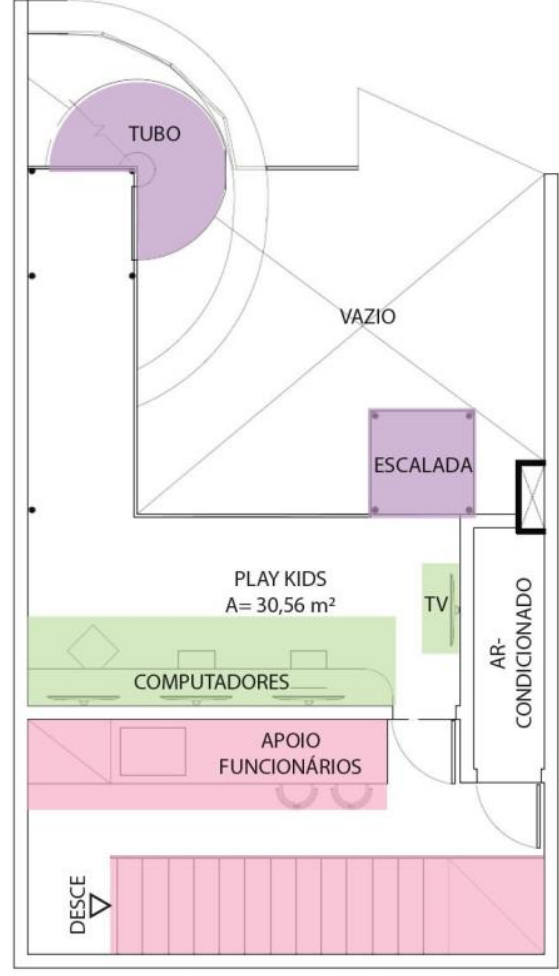

Planta Mezanino - nova proposta

LEGENDA:

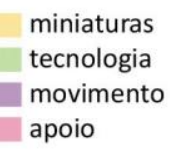

Fonte: Autoras, 2020.

A antiga área para jogos eletrônicos com uma extensa bancada, situada no andar de baixo, se misturava a diferentes brinquedos usados por crianças bem mais novas. Na nova disposição, aproveita-se o pé direito mais baixo do andar inferior devido ao mezanino para criar uma área em tons quentes, mais aconchegante, com "casinha e mercadinho" lúdicos, que podem simular uma pequena cidade adaptada à escala infantil. As cores nos tetos e piso reforçam as setorizações, e a cama elástica (brinquedo que possui maior assiduidade) é realocada para o ambiente de pé direito duplo (antigamente localizada no espaço com pé direito baixo). Além dos espelhos circulares no teto, servirem como decoração, estes refletem as imagens das crianças que estão jogando no andar superior sem precisar que as monitoras subam e desçam constantemente, podendo monitorá-los de forma rápida e eficiente.

As cores laranja e azul foram utilizadas justamente em contraposição, onde o azul fica destinado à área de brinquedos com maior movimentação e com isso transmite calma a esse espaço mais animado. Já na área com pé direito mais baixo foi utilizado o laranja para transmitir maior acolhimento e aconchego aos pequenos usuários, de acordo com os preceitos da cromoterapia. No 


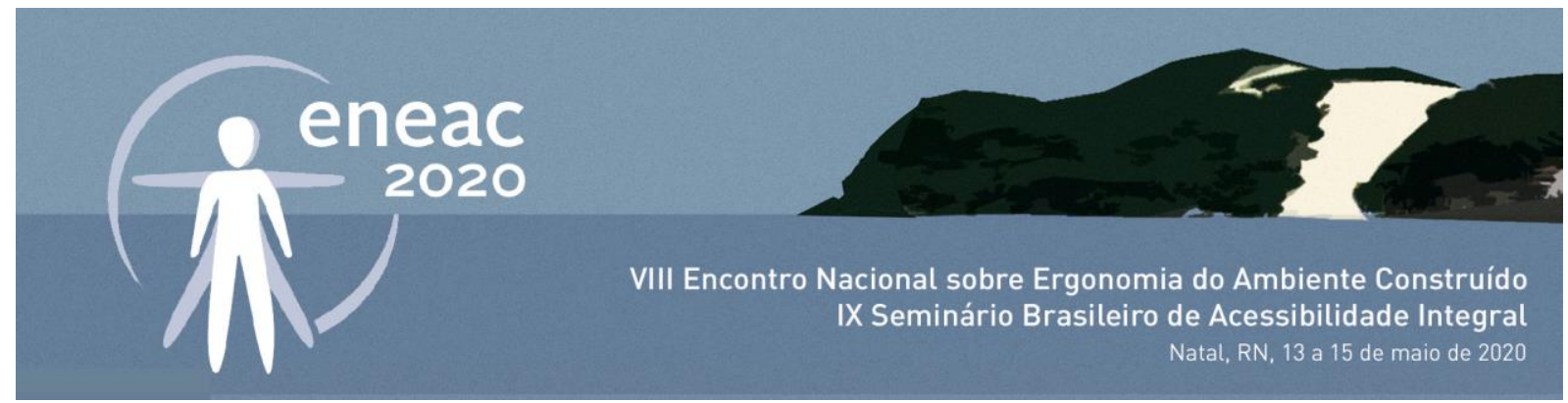

andar superior foi desenvolvido um espaço para as monitoras, onde as mesmas possam descansar em seu período de intervalo e ter a possibilidade de fazer suas refeições adequadamente com mobiliário e equipamentos disponíveis para tal atividade. Como se pode visualizar na figura 5 abaixo a proposta de novo layout para a brinquedoteca.

Figura 5: Corte longitudinal perspectivado da proposta de novo layout

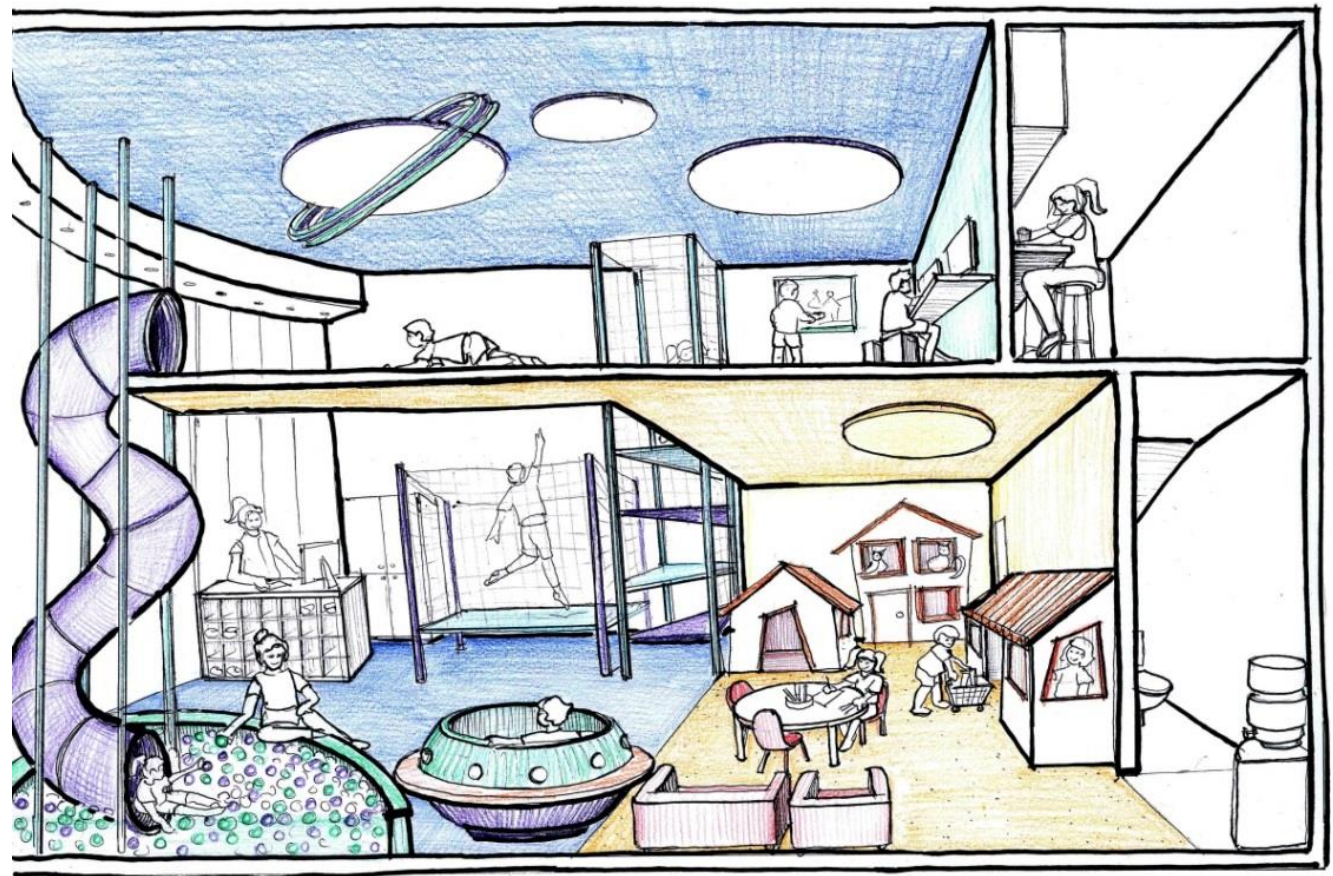

Fonte: Autoras, 2020.

Na nova disposição o caixa disposto em perpendicular ao fechamento de vidro, ficaria mais protegido (figura 6) garantindo um dos atributos mais requisitados pelas funcionárias, o da segurança. É conveniente evitar alturas de balcões que excedam 99 a 101,6 centímetros de altura. Já a dimensão recomendada para a profundidade do balcão é de 45,7 a 61 centímetros (PANERO; ZELNIK, 2002). Nesta posição, o balcão limita melhor o fluxo em um corredor de entrada com maior controle visual, distanciando também o acesso das crianças a essa restrita área de trabalho da gerente. Entrada esta que deverá ter vão livre mínimo de 80 centímetros para acesso de cadeira de rodas (ABNT, 2015).

Ainda no acesso se criou um banco de espera para os pais que anteriormente se viam obrigados a formarem filas no corredor do shopping, tumultuando ainda mais a movimentada praça de alimentação, por não possuírem espaço disponível de espera. Abaixo deste banco os próprios pais poderiam guardar os calçados dos filhos, simplificando uma das tarefas das monitoras, que exige um desconfortável movimento de agachamento repetitivo que prejudica sua postura. 


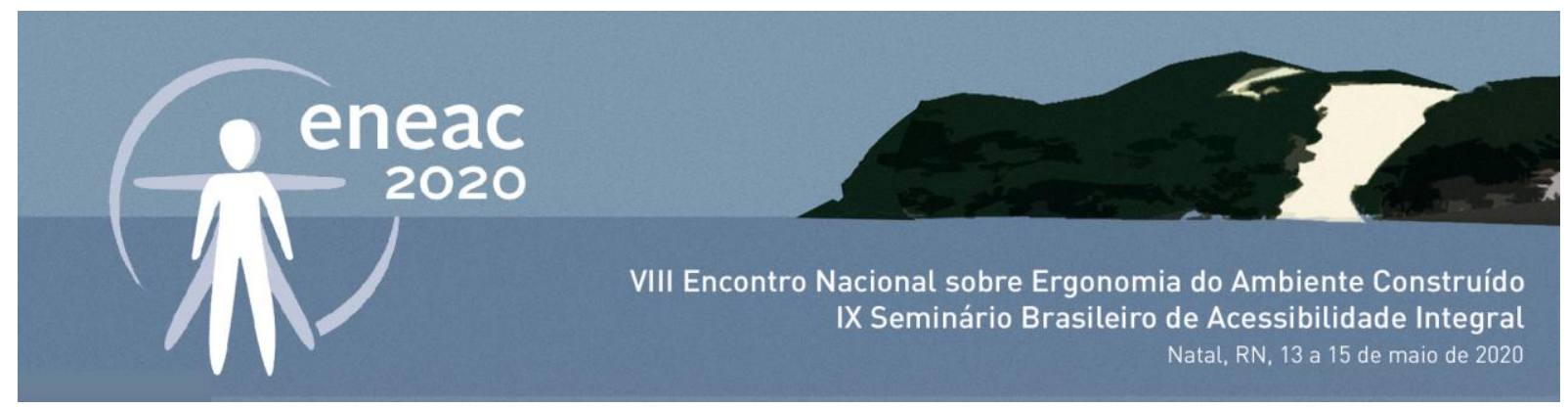

Figura 6: Fachada atual - Proposta de nova fachada
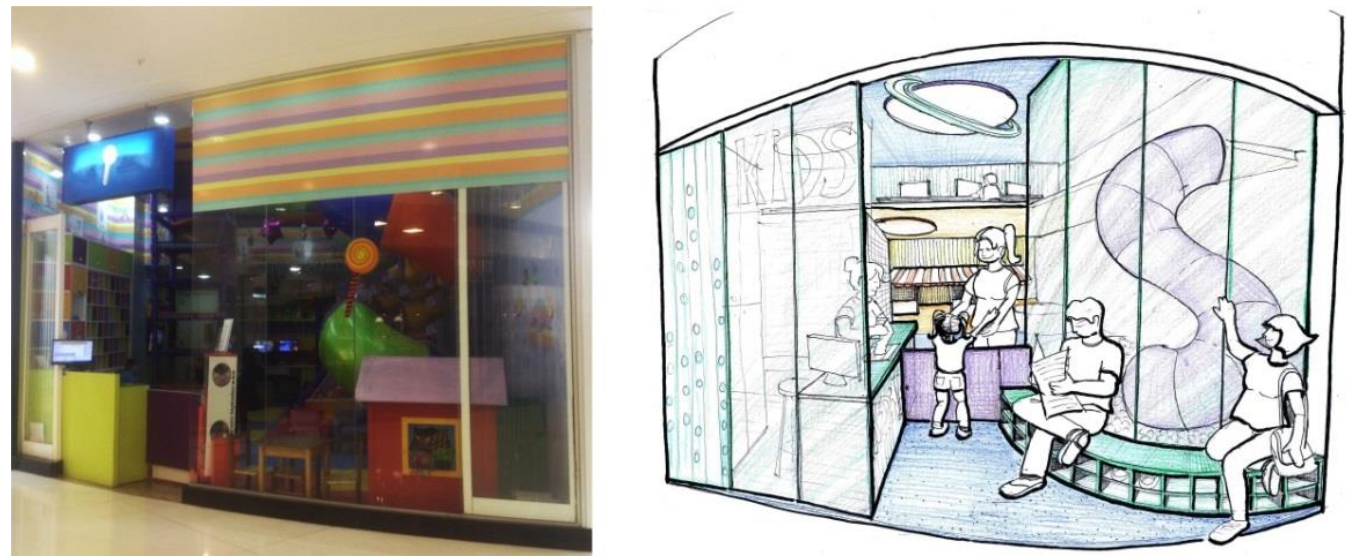

Fonte: Autoras, 2020.

Estas alterações resolveriam grande parte dos problemas apontados pelas monitoras. A nova proposta não sugere muitas mudanças estruturais, mantendo o mezanino existente, apenas alterando as posições dos brinquedos, deslocando uma única parede do ambiente superior e realocando três painéis de vidro temperado existentes na fachada. Com baixo custo, apenas com a adição de mais painéis de vidro, o movimento da curvatura da fachada de acesso à brinquedoteca seria feito por um gesto mais convidativo a mesma ao público transeunte. Assim o novo projeto espera colaborar para que pais, crianças e Alices se sintam entrando em um ambiente mais próximo ao sonhado de um país das maravilhas.

\section{CONSIDERAÇÕES FINAIS}

O presente trabalho sintetiza critérios e estratégias projetuais que possam ser aplicadas no planejamento de uma brinquedoteca sob o ponto de vista das monitoras. Tendo em vista a escassez de publicações sobre o tema, acredita-se que a análise multimétodos permitiu esclarecer algumas das necessidades e anseios do público-alvo da pesquisa. Considera-se que os diferentes olhares que a abordagem trouxe contribuem sensivelmente para que se possa ter uma visão mais abrangente e completa, permitindo assim melhor compreender os usuários.

Este artigo espera contribuir com a sensibilização de arquitetos e designers em considerar o sonho de todos que irão frequentar seus futuros projetos, escutando não apenas o proprietário e o cliente de um ambiente comercial, mas também a voz daqueles funcionários que passam a maior parte do tempo de suas vidas no estabelecimento. Todos eles merecem trabalhar em um ambiente funcional, com segurança e conforto, que respeite espacialmente a territorialidade e a privacidade, mesmo que esta dure pouco tempo de uma jornada de trabalho.

Os atributos desejáveis ao planejamento de uma brinquedoteca que mais se destacaram foram: conforto, segurança, e territorialidade, e para eles, diversas alternativas projetuais foram sugeridas. Acredita-se que sua aplicação favorecerá o uso cotidiano pelas monitoras e também pelos demais grupos de usuários. Não se pretendeu, contudo, esgotar o tema. Certamente, com a aplicação de uma amostra maior ou distinta, outros requisitos projetuais seriam evidenciados. Pretendeu-se apenas identificar alguns atributos e critérios projetuais passíveis de serem incorporadas no 


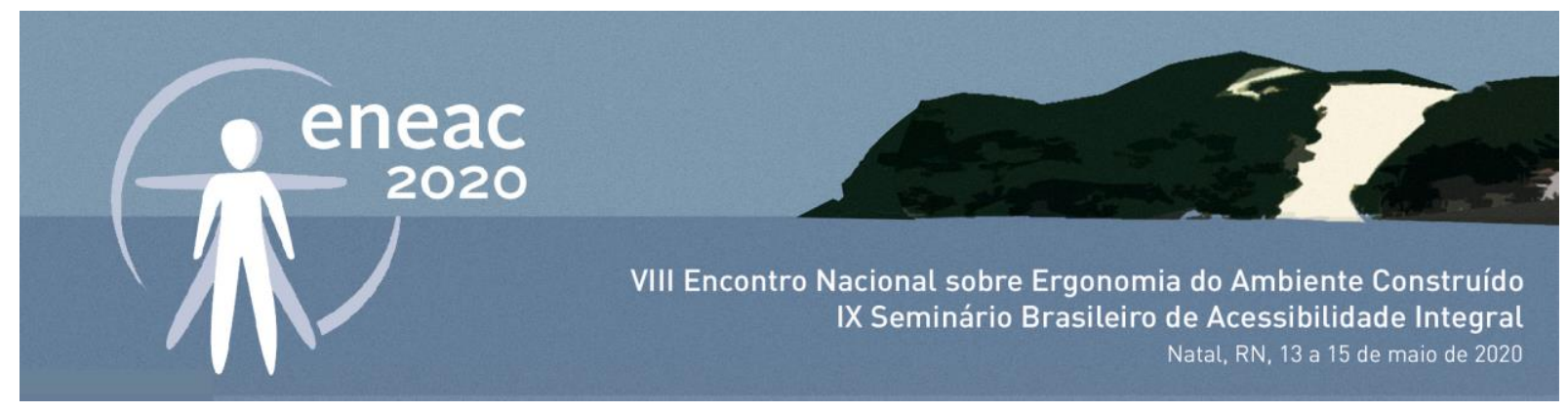

planejamento desse espaço lúdico e criativo, e que pudessem dar suporte aos monitores que utilizam esse espaço no dia a dia.

\section{AGRADECIMENTOS}

As autoras deste artigo agradecem a UNIEDU/FUMDES que possibilita a bolsa de estudos durante o período do mestrado e ao Programa de Pós-Graduação em Arquitetura e Urbanismo da UFSC pelo apoio na realização da pesquisa.

\section{REFERÊNCIAS}

ABBRI. Associação Brasileira de Brinquedotecas. Histórico. ABBri Associação Brasileira de Brinquedotecas. [s.I.], 2017.

Disponível em: http://www.brinquedoteca.org.br/historico/. Acesso em 22 de out. de 2019.

ABRAHÃO, J. et al. Introdução à Ergonomia: da teoria à prática. São Paulo: Blücher, 2009.

ASSOCIAÇÃO BRASILEIRA DE NORMAS TÉCNICAS. NBR 9050: Acessibilidade a edificações, mobiliário, espaços e equipamentos urbanos. Rio de Janeiro, 2015. 148p.

BARDIN, L. Análise do Conteúdo. São Paulo: Almedina, 2011.

BELL, P. A. et al. Environmental Psychology. Londres: Psychology Press, 1978.

CBO - CLASSIFICAÇÃO BRASILEIRA DE OCUPAÇÕES. Ministério do trabalho. Brasília, 2020. Disponível em:

http://www.mtecbo.gov.br/cbosite/pages/pesquisas/ResultadoOcupacaoMovimentacao.jsf. Acesso em: 09 jan. 2020.

CAVALCANTE, S. A porta e suas múltiplas significações. Estudos de Psicologia, Natal: v. 8, n. 2, pp. 281-288, 2003.

DUL, J.; WEERDMEESTER, B. Ergonomia Prática. São Paulo: Blücher, 2004.

GIFFORD, R. Environmental Psychology: principles and practice. Nova York: Optimal Books, 1987.

IIDA, I. Ergonomia: projeto e produção. São Paulo: Blucher, 2005.

ITLA, Internacional Toy Library Association. About ITLA. ITLA. [s.I.], 2020. Disponível em: http://itlatoylibraries.org/home/about-itla/. Acesso em 22 out. 2019.

ITTELSON, W. H. et al. An Introduction to Environmental Psychology. Nova York: Holt, Rinehart \& Winston, 1974.

KROEMER, K. H.; GRANDJEAN, E. Manual de ergonomia: adaptando o trabalho ao homem. Porto Alegre: Bookman, 2005.

LIMA, L. R.; DELMÔNICO, R. L. Estudo Sobre a Importância da Brinquedoteca no Ambiente Escolar como Espaço Mediador de Aprendizagens, Sob o Ponto de Vista dos Professores da Rede Municipal de Ensino do Cornélio Procópio. Só pedagogia. Rio Grande do Sul, 2010. Disponível em:

http://www.pedagogia.com.br/artigos/importanciadabrinquedoteca1/index.php?pagina=0. Acesso em: 23 out. 2019.

MOSER, G. Psicologia Ambiental. Estudos de Psicologia, Natal: v. 3, n. 1, pp. 121-131, 1998.

PANERO, J.; ZELNIK, M. Dimensionamento humano para espaços interiores: um livro de consulta e referência para projetos. Barcelona: Editorial Gustavo Gili, 2002.

RHEINGANTZ, P. A. et al. Observando a qualidade do lugar: procedimentos para a avaliação pós-ocupação. Rio de Janeiro: Universidade Federal do Rio de Janeiro, 2009.

RICO, F. 15 frases e diálogos de Alice no País das Maravilhas. Culturalizando, [s.I.], 2015. Disponível em: http://culturalizando.wixsite.com/culturalizando/single-post/2015/12/09/15-frases-e-di\%C3\%A1logos-de-Alice-noPa\%C3\%ADs-das-Maravilhas. Acesso em: 22 out. 2019.

SANOFF, H. Participatory Design: Theory and Techniques. North Carolina: North Carolina State University, 1990.

SILVEIRA, C. M. F.; BINS ELY, V. H. M. Avaliação do trabalho dos atendentes em panificadora sob o viés da psicologia ambiental e da ergonomia. In: Encontro Nacional e Latino-Americano de Conforto no Ambiente Construído, Campinas: Anais do XIII ENCAC/ IX ELACAC, 2015. 